\title{
The Noun: A Comparative Analysis between the Arabic and the English Languages
}

\author{
Syed Sahid Ahammad \\ Assistant Professor, Department of Islamic Studies, Uttara University, Dhaka, Bangladesh
}

\begin{abstract}
In the history of civilization different human races have created different languages to express their thoughts, ideas, feelings and emotions. With the passage of time the world has become a global village and at the moment, we should know different languages to understand each other easily. Noun is one of the most significant components of all languages. We cannot think the existence of a language without noun. In this article, a comparative analysis of noun of Arabic language and English language has been made which will discover the similarities between the languages. This article is expected to explore some important aspects of Noun in both Arabic and English languages by applying qualitative and analytical research methods.
\end{abstract}

Keywords: Noun, English, Arabic, Language.

\section{INTRODUCTION}

The noun is one of the significant parts of any language. A noun ( from Latin nõmen, literally meaning "name" $)^{1}$ is a word that functions as the name of some specific thing or set of things, such as living creatures, objects, places, actions, qualities, states, of existence, or ideas. ${ }^{2}$ Linguistically, a noun is a member of a large, open part of speech whose members can occur as the main word in the subject of a clause, the object of a verb, or the object of a preposition. ${ }^{3}$

\section{THE NOUN IN ENGLISH}

It is, according to English grammarians, a word, which can act as the subject or object of a verb, or the object of a preposition. Alternatively, we can say that a noun is a word is used as the name of a person, place or thing. ${ }^{5}$ According to 'İzuddin Mohammad Nazib,

الإسم هو ما نطلقه علي شيئ أو شخص أو حالة .....الخ

"Noun is a word that is the name of something (such as a person, animal, place, quality, idea or action) and is typically used in a sentence as subject of a verb as object of a preposition." 6

On the other hand, nouns are frequently defined, partiularly in informal contexts, in terms of their semantic properties (their meanings). Nouns are described as words that refer to a person, place, thing, event, substance, quality, and others. However this type of definition has been criticized by contemporary linguistics as being uninformative. 7

Let us examine the flowing examples and find out the italic words:

Nazrul was a great poet.

Dhaka is on the Buriganga.

The rose smells sweet.

The sun shines bright.

\section{The noun in Arabic} follows:

Exponents of Arabic grammarians have been given many definitions as to noun (إسم). Some are as

*It has a meaning which is not dependant on any of the three times the past (الماضي) or the present (أو الحال) or the future (أو الإستقبال).

Some say, Noun (إسم) is the 'كلمة' that gives a full independent meaning in itself and is not linked to time, e.g. رجل (man), بيت (house). The category is broader than 'noun' in that it also includes three others from the eight English parts of speech, namely pronouns, adjectives and adverbs. 
Al Hashemi has said, "It is, therefore, implicitly said that noun in Arabic, is a name of a person, place or object. It does not have any tense." 9

According to Abdul Maseh,

الإسم هو مايدل علي معني مستقل بالفهم ليس الزمن جزءا منه

"The noun which can express its meaning by itself alone. Moreover, it need not indicate any period i.e. present, past and future.',10

Abul Hashem defines noun as "a word which is sufficient to express its meaning alone. Beside that, it does not indicate any particular tense or period, i.e. present, past and future." 11

\section{TYPES OF NOUN IN ENGLISH}

In English language, there are two main types of noun, namely; Concrete nouns and Abstract nouns.

\subsection{Concrete nouns}

A concrete noun denotes something material and no abstract, as chair, house, or automobile. This type of noun refers to objects and substances, including people and animals, that exist physically. ${ }^{12}$ Further, according to I'zuddin Mohammad Nazib:

إسم مجسمة (concrete noun) هي كل ما يمكن رؤيته بالعين أو إدر اكه بالحواس أو بالأجهزة المختلفة

"The concrete noun that can be seen by the eye or perceive the senses or the various equipment",13

The concrete noun further can be:

1. Common noun;

2. Proper noun; and

3. Collective noun.

\subsubsection{Common noun}

A common noun is a name given in the common to every person or thing of the same class or kind. An Arab grammarian states;

إسم عامة (common noun) هو ما يطلق علي أب فرد من نوع معين من الناس أو الحيونات أو الأشياء

"A common noun are words used to name general items rather than specific ones", 14

For example:

man, boy, girl;

tree, grass, flower;

dog, owl, lion;

box, pen, book;

day, month, year etc.

\subsubsection{Proper ${ }^{15}$ noun}

A proper noun or proper name is a noun representing unique entities (such as India, Jupiter, Harry, or BMW), as distinguished from common nouns which describe a class of entities (such as city, animal, planet, person or car). ${ }^{16}$

Again, define proper noun as:

$$
\text { هو إسم علم (proper noun) ما يطلق علي فرد بعينه ويبدأ بحرف كبير }
$$

"A proper noun is the name of some particular person or place. These nouns are always written with a capital letter at the beginning", ${ }^{17}$ For examples:

Ali, Sami, Rumi,

Rex, Pussy, Amazon,

Cairo, London, China,

Islam, Buddhism, Hinduism,

January, February, March,

Sunday, Monday, Tuesday,etc. 


\subsubsection{Collective noun}

A collective noun is the name of a number or collection of persons or things taken together and spoken of as a unit or group. These nouns may be followed by a singular or a plural verb and referred to by a singular or plural pronoun, the singular being generally preferred when referring to the body as a unit and the plural often being preferred, especially in British English, when emphasizing the individual members. Examples of acceptable and unacceptable use given by Gowers in Plain Works include. ${ }^{18}$

crowd, mob, team,

board, committee etc.

\section{2. Abstract noun}

An abstract noun is the name of a quality, action or state considered apart from the object from the to which it belongs, such as truth, beauty or goodness and others. "It is an object which does not exist at any particular time or place, but rather exists as a type of thing, i.e., an idea, or abstraction.", 19

This type of noun that also refers to something with which a person cannot physically interact. However, in many cases, the 'thing' might be an intangible concept - which means it is an abstract form of noun. ${ }^{20}$

\section{Types Of Noun In Arabic Language}

Exponents of Arab grammarians have divided nouns (ألإسم) as:

ينقسم الاسم إلي أقسام كثيرة باعتبارات مختلفاة وهي:

(the noun) is divided into many sections of different considerations, namely:

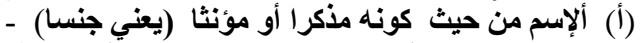

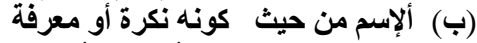

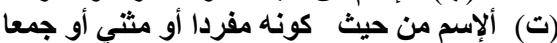

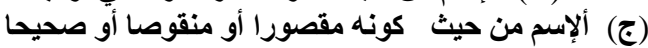

i.e. The noun is divided into many sections of different consideration, namely:

(1) Types of noun in terms of genders;

(2) Types of noun in terms of Articles;

(3) Types of noun in terms of numbers (singular and plural);

(4) Types of noun in terms of structures. ${ }^{21}$

\subsection{Types of noun in terms of genders ${ }^{22}$ (i.e. analysis of noun in genders perspective)}

Every noun inherently carries one value of the grammatical category called gender; ${ }^{23}$ the values present in a given language (of which there are usually two or three) are called the genders of English language. According to one definition: "Genders are classes of nouns reflected in the behavior of associated words.",24

With regard to gender (الجنس), Arabic nouns are divided into two categories:25 (مذكر)(1) Masculine (2) Feminine (مؤنث). It is essential to know the gender of all kinds of nouns as the verbs and adjectives have to agree in respect of the gender of their subjects and the nouns qualified. ${ }^{26}$

Whole words in Arabic language are either Masculine or feminine. There is no neuter or common gender. ${ }^{27}$

\subsubsection{Rules of Gender (الجنس) in Arabic}

a. Agreement of the verb with its subject; for example:

$$
\text { Hamid wrote (كتب حامد) }
$$

Fatima wrote (كتبت فاطمة)

In the above examples, for (كامد) the verb is (كامدة) (كتبت) tكe verb is (كتب). Though the verb in both the examples is same, in the first example it is masculine but in the second, it is feminine.

b. Agreement of the adjective with the noun; for example;

The intelligent boy (الولد الذئي)

The intelligent girl (البنثُ الذكية)

It is better to mark the ( ()$^{28}$ at the end of the feminine adjective. Arabic feminine refers to female qualities attributed specifically to women and girls or things considered feminine.

The complement to feminine is masculine. Feminine Genders are of two types. Here are some examples:

i. The natural or real feminine (هؤنث حقيقى).These are nouns denoting females. e.g.

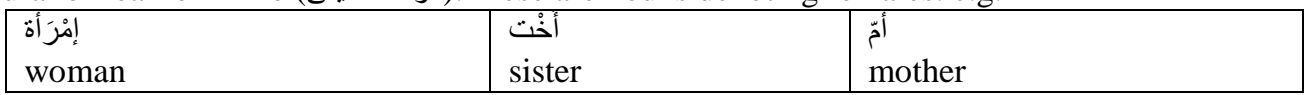

ii. The unreal or supposed feminine(مؤنت غيرحقيقى):

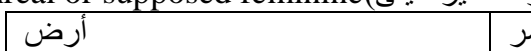




\begin{tabular}{|l|l|l|}
\hline earth & moon & city \\
\hline
\end{tabular}

Masculine nouns do not require any sign to signify their gender. However, the feminine nouns usually end in three specific ways.

c. Feminine ending with $(\ddot{0})^{30}:$ e.g.

\begin{tabular}{|l|l|l|l|}
\hline $\begin{array}{l}\text { حسبية } \\
\text { beloved }\end{array}$ & $\begin{array}{l}\text { ظعلمة } \\
\text { blessing } \\
\text { power }\end{array}$ & darkness \\
\hline
\end{tabular}

b. Feminine ending with (الف المقصورة), the shortened (الف);

Examples:

\begin{tabular}{|l|l|l|l|}
\hline $\begin{array}{l}\text { (بشرى } \\
\text { red }\end{array}$ & $\begin{array}{l}\text { حَسنى } \\
\text { good news }\end{array}$ & big & noble lady \\
\hline
\end{tabular}

c. Feminine ending with الالف الممدوده, the stretched: Examples:

\begin{tabular}{|c|c|c|c|}
\hline $\begin{array}{l}\text { بيضاء } \\
\text { fair lady }\end{array}$ & صحراء & $\begin{array}{l}\text { كبرياء } \\
\text { pride }\end{array}$ & $\begin{array}{l}\text { سوداء } \\
\text { black }\end{array}$ \\
\hline
\end{tabular}

Here is a list of nouns which are feminine though they are devoid of the signs to that effect;

* Parts of human body which are in pairs, but حاجب eye brow are masculine; ${ }^{31}$ for example:

\begin{tabular}{|c|c|c|c|c|}
\hline $\begin{array}{l}\text { ثاى } \\
\text { breast }\end{array}$ & $\begin{array}{l}\text { بnd } \\
\text { hand }\end{array}$ & $\begin{array}{l}\text { أصبع } \\
\text { finger }\end{array}$ & $\begin{array}{l}\text { eye } \\
\text { eye }\end{array}$ & $\begin{array}{l}\text { ساق } \\
\text { shank }\end{array}$ \\
\hline قدم & $\begin{array}{l}\text { رجل } \\
\text { leg }\end{array}$ & $\begin{array}{l}\text { أذن } \\
\text { ear }\end{array}$ & $\begin{array}{l}\text { نخذ } \\
\text { thigh }\end{array}$ & $\begin{array}{l}\text { كتف shoulder } \\
\text { shol }\end{array}$ \\
\hline
\end{tabular}

* Some natural objects which are feminine by mere usage; for example:

\begin{tabular}{|l|l|l|l|l|}
\hline $\begin{array}{l}\text { جنuntain } \\
\text { moun }\end{array}$ & fire & wind & sea & soul \\
\hline
\end{tabular}

* Some objects are occasionally used as masculine; for example:

\begin{tabular}{|c|c|c|c|c|c|}
\hline $\begin{array}{l}\text { عtaff } \\
\text { stal }\end{array}$ & فرش & $\begin{array}{l}\text { بئر } \\
\text { well }\end{array}$ & $\begin{array}{l}\text { خمe } \\
\text { wine }\end{array}$ & سماء & $\begin{array}{l}\text { دار } \\
\text { house }\end{array}$ \\
\hline كأس & $\begin{array}{l}\text { سكين } \\
\text { knife }\end{array}$ & $\begin{array}{l}\text { جنll } \\
\text { hell }\end{array}$ & $\begin{array}{l}\text { حديقة } \\
\text { garden }\end{array}$ & $\begin{array}{l}\text { حرب } \\
\text { war }\end{array}$ & $\begin{array}{l}\text { لغة language } \\
\text { la }\end{array}$ \\
\hline
\end{tabular}

* Names of countries, cities and tribes; as feminine: for example:

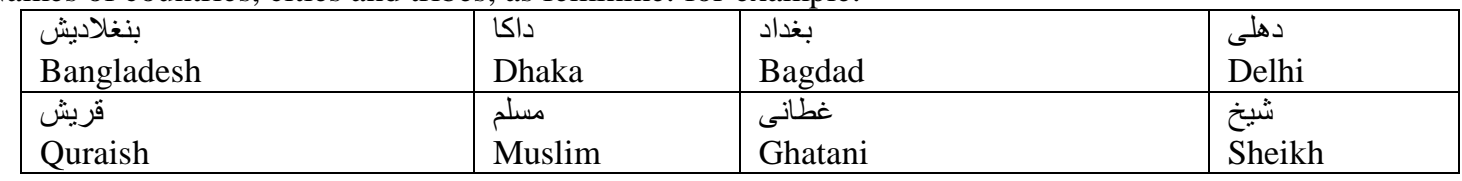

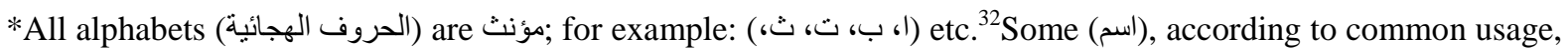
are (مؤن):

\begin{tabular}{|l|l|l|l|}
\hline $\begin{array}{l}\text { أرضم } \\
\text { earth }\end{array}$ & $\begin{array}{l}\text { (م) } \\
\text { banana }\end{array}$ & $\begin{array}{l}\text { bruit } \\
\text { fun }\end{array}$ & \\
\hline
\end{tabular}

\subsection{Types of noun in terms of definite and indefinite:}

A noun is either definite (i.e. المعرفة) or indefinite (i.e. النكرة). An indefinite noun can be defined as 'the

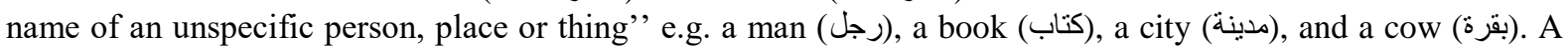
definite noun can be defined as "the name of a specific person, place or thing” e.g. Abdullah (عبداب), Bagdad (بغداد), Black stone (الحجر).

On the other hand, the word "Al", is called definite article (i.e. المعرفة), i.e. Al-ال, is the definite article in the Arabic language: whose function is to render the noun which it is prefixed definite. For example, the word (الجديقة) 'garden 'can be made definite by prefixing it with al-, resulting in (الجديقة) al-hadiqah "the garden". Consequently, al-is typically translated as the in English language.

In English, there are two types of articles are "The" is definite article and "A, An" are the indefinite articles.

\subsection{Types of noun in terms of numbers (singular and plural):}

In English and the Arabic language, grammatical number is a category of nouns, pronouns, adjective and verb agreement that expresses count distinctions (such as "one', "two", or "three or more" ${ }^{33}$. In English language, the number categories are singular and plural. But in Arabic language, have a dual with singular and plural numbers; that means singular (واحد), dual (تمع) (تثع). Both of English and Arabic languages, the subject of a sentence and its verbs must agree in number. ${ }^{34}$ 
Number denotes singularity and plurality of a noun. The noun form of a word, showing whether one or more than one person or thing is being talked about; the word 'men' is plural in number. Again in the English language, there are two types of number separately:

i. Singular (المفرد): This noun denotes one person or thing is said to be in the singular number. For example: boy, girl, cow, pen and others.

ii. ralPlu (الجمع): ${ }^{35}$ Plural is one kind of the types of noun that denotes more than one person or thing. Most commonly, therefore, plurals are used to denote two or more of something, although they may also denote more than fractional, zero or negative amounts. Such as cats, this corresponds to the singular cat. i.e. A Noun that denotes more than one person or things is called a plural. Examples:

boys, girls, cows, birds,

trees, books, pens, taxes, boxes etc.

In Arabic, there are three numbers:

i. Singular (المفرد): ${ }^{36}$ A Noun that denotes one person or thing is called singular number,e.g.

\begin{tabular}{|l|l|l|}
\hline bey & $\begin{array}{l}\text { a } \\
\text { bow }\end{array}$ & $\begin{array}{l}\text { pen } \\
\text { cow }\end{array}$ \\
\hline
\end{tabular}

ii. Dual (المثنى): $:^{37}$ A noun that denotes two persons or things is called dual number, e.g.

\begin{tabular}{|l|l|l|}
\hline $\begin{array}{l}\text { خقادنان } \\
\text { two servants }\end{array}$ & $\begin{array}{l}\text { two cows } \\
\text { two pens }\end{array}$ \\
\hline
\end{tabular}

iii. Plural (الجمع): ${ }^{38}$ A Noun that denotes more than two persons or things is called plural number, e.g.

\begin{tabular}{|l|l|l|}
\hline Many servants & $\begin{array}{l}\text { أقلام } \\
\text { Many cows }\end{array}$ & many pens \\
\hline
\end{tabular}

*Rules of Plurals in English

i. The plural form of noun is generally constituted by adding 's' to the singular form of a noun. For examples:

\begin{tabular}{|l|l|}
\hline Singular & Plural \\
\hline Boy & Boys \\
\hline Girl & Girls \\
\hline Book & Books etc. \\
\hline
\end{tabular}

ii. Nouns ending in's', 'sh', and 'ch' are made plural by adding 'es' at the end. For examples: ${ }^{39}$

\begin{tabular}{|l|l|}
\hline Singular & Plural \\
\hline Class & Classes \\
\hline Match & Matches \\
\hline Box & Boxes \\
\hline
\end{tabular}

iii. Most Nouns ending in 'o' also turn plural by taking 'es' at the end:

\begin{tabular}{|l|l|}
\hline Singular & Plural \\
\hline Potato & Potatoes \\
\hline Mosquito & Mosquitoes \\
\hline Mango & Mangoes \\
\hline
\end{tabular}

iv. Few nouns ending in 'o' need's' to be plural:

\begin{tabular}{|l|l|}
\hline Singular & Plural \\
\hline Piano & Pianos \\
\hline Photo & Photos \\
\hline Dynamo & Dynamos \\
\hline
\end{tabular}

V. Nouns ending in ' $y$ ', preceded by a consonant, form their plural by changing ' $y$ ' into ' $i$ ' and adding 'es' thereto; for example:

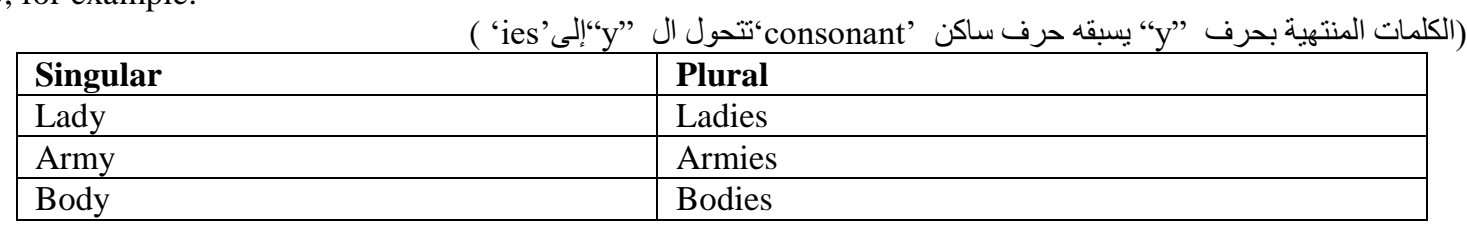

vi. The following nouns ending with ' $\mathrm{f}$ ' or ' $\mathrm{fe}$ ' change into plural by adding 'ves' replacing ' $f$ ' or ' $f e$ '. For example:

\begin{tabular}{|l|l|}
\hline Singular & Plural \\
\hline Thief & Thieves \\
\hline
\end{tabular}


The Noun: A Comparative Analysis Between The Arabic And The English Languages

\begin{tabular}{|l|l|}
\hline Wife & Wives \\
\hline Knife & Knives \\
\hline
\end{tabular}

* Rules of duals and plurals in Arabic

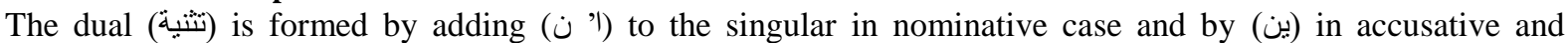
genitive cases, e.g.

\begin{tabular}{|l|l|}
\hline Singular & Plural \\
\hline a man & $\begin{array}{l}\text { رجلان } \\
\text { a }\end{array}$ \\
\hline عينين & two men \\
an eye & two eyes \\
\hline
\end{tabular}

A word in the dual number does not admit التنوين Nunation'. ${ }^{40}$ Some grammarians of the Arabic language said that (اسم) has the same form for the accusative and genitive cases. It may be called the oblique case. For example; (عثنى) from (عين) is (عين) in (عنان) in the nominative case and ique case."41

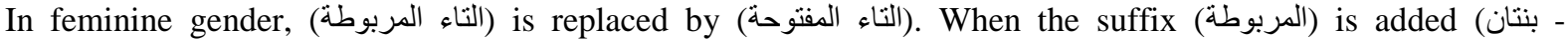
nominative) and (بنتين) are (مثنى) formed. Example; (خادمتين بنت خادمتان) are (خادمة)-a female servant).

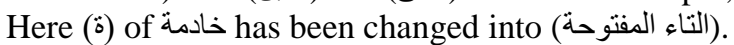

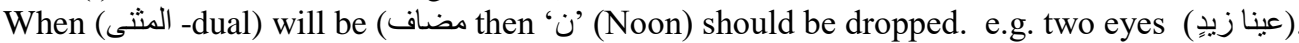

Types of Plural: ${ }^{42}$ There are two types of (جمع -plural number) in Arabic language,

i. The sound plural (الجمع السالم) (الجكعر)

ii. The broken plural (الجمع المكسر)

i. The sound plural (الجمع السالم): ${ }^{43}$ When a plural retains all the vowels and consonants of the singular and is based on its pattern it is known as (الجمع السالم) the sound plural. In most of the authoritative Arabic dictionaries the plural of all categories of nouns are mentioned along with their meanings. It may be mentioned here that in English plurals cannot be classified into other types. Here some examples of (الجمع الذكر السالم - the sound plural) masculine:

\begin{tabular}{|c|c|c|}
\hline English words & Plural & Singular \\
\hline Writer & كاتبون or كاتبين & كاتب \\
\hline Egyptian & مصريون or مصرين & مصرى \\
\hline Believer & مؤمنون or مؤمنين & مؤمن \\
\hline Learned & عالمون or عالمين & عالم \\
\hline
\end{tabular}

Here some examples of ( الجمع المؤنث السالم- the sound plural) ${ }^{44}$ feminine:

\begin{tabular}{|c|c|}
\hline Plural & Singular \\
\hline زينبات & زينب \\
\hline هندات & هند هن \\
\hline فاطمات & فاطمة \\
\hline شجر ات & شجرة \\
\hline
\end{tabular}

ii. The broken plural (الجمع المكسر): ${ }^{45}$ In Arabic, the broken plurals are known as (تَمَعسير). These plurals constitute one of the most unusual aspects of the language, given the very strong and highly detailed grammar and derivation rules that govern the written language. Broken plurals can also be found in languages that have borrowed many words from Arabic, for instance Persian, Pashto, Turkish, Kurdish, Azerbaijani and Urdu, and sometimes exist in both a broken plural Arabic form and a local, adapted plural, e.g. in Pashto where the word for purpose (مطلب) can be pluralized in either its Arabic form (مطالب) for more formal, High Pashto, or the

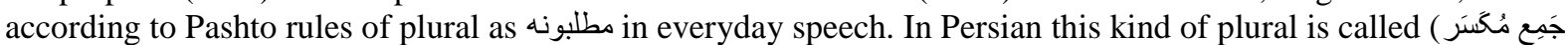
- broken plural). ${ }^{46}$

It is said that, the commonality is in the root consonants, not the vowels. Here are some few examples; (الجمع المكسر:

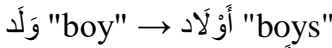

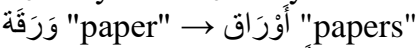

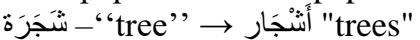

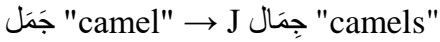


"desk, office" $\rightarrow$ مَكَتَبَ "offices"

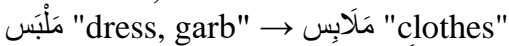

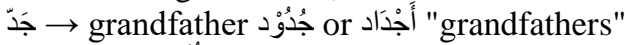

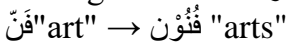

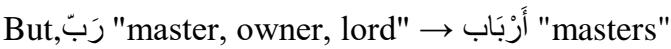

It is said that the plural of (إمراة-woman) is ( نساء-women). Beside nouns and adjectives, verbs and pronouns too are converted into dual and plural numbers in Arabic. ${ }^{47}$

\subsubsection{Types of noun in terms of structures}

In Arabic, Nouns (أسماء) are of three types:

i. Primary noun (جامد): that noun (إسم) which neither derived from another word nor is any word derived from it. e.g

\begin{tabular}{|c|c|}
\hline $\begin{array}{l}\text { فَرَسُ } \\
\text { horse }\end{array}$ & 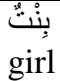 \\
\hline
\end{tabular}

ii. Derivative (مصدر): that noun from which many words are derived. ${ }^{48}$ e.g.

\begin{tabular}{|l|l|}
\hline $\begin{array}{l}\text { ضُصَرَ } \\
\text { to hit }\end{array}$ & to help \\
\hline
\end{tabular}

iii. Root noun (مشتق): that noun from which is derived from a (مصدر)).e.g.

\begin{tabular}{|c|c|}
\hline ضَتارُُِ & $\begin{array}{l}\text { مَنْصُوْرُ } \\
\text { the helped }\end{array}$ \\
\hline
\end{tabular}

Ibn Hisham al-Ansari, an expert on Arabic grammar, divided Arabic Nouns into different types. ${ }^{49}$

These are as follows:

4.4.2. Simple Nouns:

\begin{tabular}{|c|c|c|c|c|c|}
\hline $\begin{array}{l}\text { Common } \\
\text { e.g. (كِكَبُبُ)* }\end{array}$ & 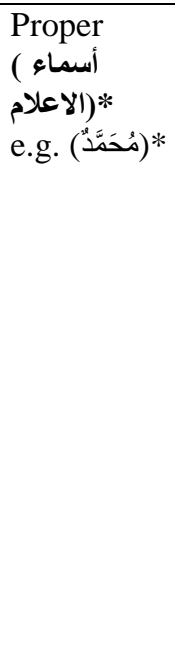 & 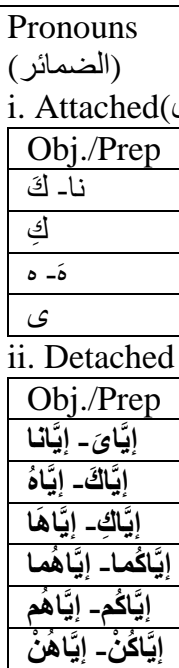 & 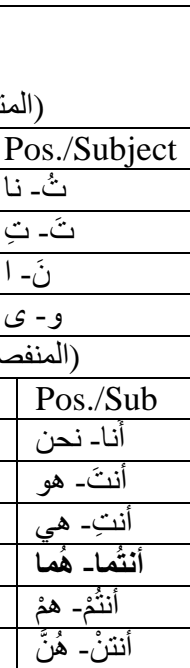 & 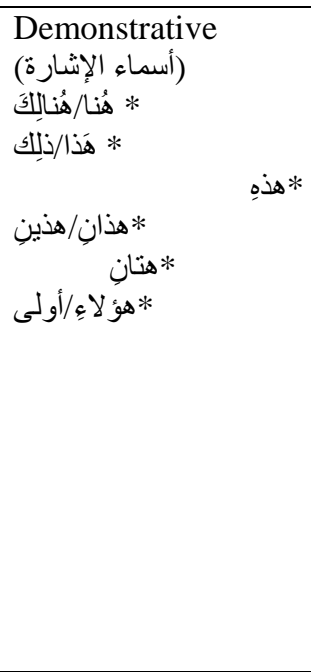 & 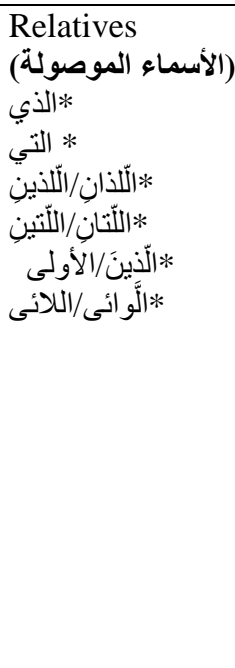 \\
\hline
\end{tabular}

*. Five Nouns (الأسماء الخمسة):

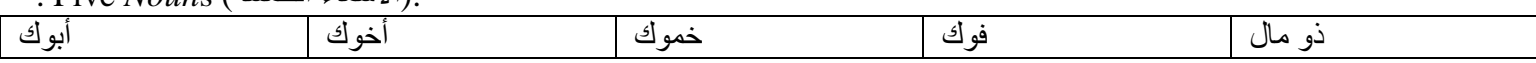

*. Foreign Nouns (أأسماء الأجنبية):e.g. (أبر اهيم'يوسف).

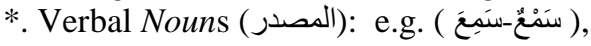

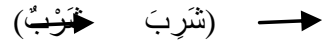

\section{FINDINGS}

i. In English, noun indicates the name of a person, place, or thing. It is an individual parts of speech; whereas in Arabic, noun (إسم) includes nouns, pronouns, adjectives, adverbs and some interjections.

ii. In English, noun is of two types, in particular, by purpose and by structure; but in Arabic, it has been included by three types: i. Primary noun (إسم الجامد), ii. Derivative (إسم المصدر) and iii. Root noun (إسم المشنق)

iii. In English, there are two articles, definite (the) \& indefinite (a, an), whereas there is only one article (الج) is the definite article. It is equivalent to the word 'a', 'an' and 'the' in English. 
iv. In English, the plural form of noun is generally formed by adding "s", "es", "ies", and "ves"; whereas

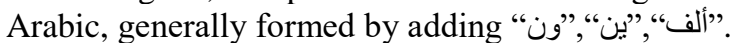

v. All these Arabic sentences consist of two nouns, but in the English translation, invariably the auxiliary verbs (is) and (are) are used to complete the predicate.

vi. In English, there are two types of number, in particular, singular and plural; on the other hand, there are three numbers (العدد), namely: i.) singular number (المدرد) ii) Dual number (الجمع) (المثني) iii) Plural number i.e. There is no dual in English Demonstrative; but In Arabic dual of Demonstrative are ذان (ذان (two) are these (two) are etc.

vii. In English language only nouns and pronouns can take plural form; In Arabic adjectives and verbs can also be in plural forms.

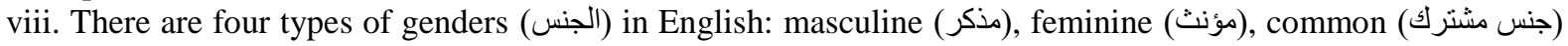
and neuter (مجازى); In Arabic have only two: (مونث) (مون) and (منثر).

ix. The $3^{\text {rd }}$ person masculine are used by him: his, them: there, them: their; the $3^{\text {rd }}$ person (غائب مذكر) masculine are used by $\bullet$ (him: his), Lo (them: their), ه (them: their).

$x$. The $3^{\text {rd }}$ person feminine is used by his: her, them: there, them: their in English; but the $3^{\text {rd }}$ person feminine are used by \& (his: her), هo (them: their) \& ه (them: their) in Arabic language.

xi. $2^{\text {nd }}$ person masculine are used by you: your, you: your, you: your; on the other hand, $2^{\text {nd }}$ person masculine are

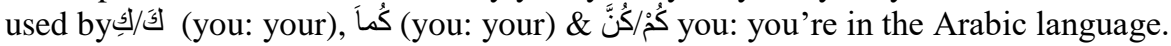

\section{CONCLUSIONS}

There lies no denying the fact that in both English and Arabic the noun holds a place of singular importance as a part of speech. The area of noun in English is limited but in Arabic its area is vaster. Noun in English means the names of person, place or thing; but Arabic noun includes nouns, pronouns, adjectives, adverbs and some interjections. In terms of categories, English noun differs; the morphological studies have revealed the facts that both the English and the Arabic, noun has some identical similarities which have brought the two languages close other linguistic research.

\section{BIBLIOGRAPHY}

[1]. Charlton T. Lewis and Charles Short. A Latin Dectionary (Newyourk: Oxford University Press. Fisrt ed.1875, last ed.1947)

[2]. Merriam - Webstar Dectionary (online) Merriam - Webstar, Incorporated 2014

[3]. Loos, Eugene. Et al 2003. Glossary of linguistic terms; what is noun?

[4]. Al-Bayati, Tahir, Al-Lugah Al-Engiligiyyah (Beirut: Al-Ahliyyah publishers, 2nd edi. 2008)

[5]. Wren \& Martin, High School English Grammar and Composition (New Delhi, S. Chad \& Company, 7361, Ram Nagar)

[6]. Nazib, 'Izuddin Muhammad, Qawai'dullugah Al-Engiligiyyah (Cairo: Ibn Sina bookshop, Helopolis , 8th edi. 1996 )

[7]. Jeckendoff. Ray. (2002) "Semantics as a generative system", Foundations of language; brain, meaning, grammar, evolution (PDF), Oxford University Press. ISBN 0-19-827012-7.

[8]. Muhyi al-Din 'Abd al-Hamid, Muḥammad, Sharh Ibn 'Aqil 'ala Alfiyyat Ibn Malik wa-ma'ahu Kitab Minḥat al-Jalil bi-Tahqiq Ibn 'Aqil. (Cairo: Maktab al-Turath,v-1)

[9]. Assyyed Al-Hashemi, Qawaed Alluyah al Arabiyyah ( Beirut:Dar al kutub)

[10]. Dr. Zawarez Marti Abdul Maseh, Ma'zamu Qawa'id-ul 'Arabiyyatul al-'Alamiyyah (Beirut: Maktabatu

[11]. Lebanon Nasherun, 2nd ed. 1995)

[12]. Abul Hashem, Arabic Made Easy (Chittagong: Bangladesh Co-Operative Society Ltd.)

[13]. Larry Beason (2005), The Mc Graw-Hill Handbook of English Grammar and Usage, (Chicago: Mc Graw publication )

[14]. Dr. Nazeeb , I'zuddin Muhammad, Qawaidullugah Al Arabiyyah (Cairo: Maktabatu Ibn Sina, Haliopolis, 8th edition,19 94.)

[15]. Haywood \& Nahmad, A New Arabic Grammar of the Written Language (New York: Columbia University Press, second edition 1997 first published in 1965)

[16]. Proper means one's own. Hence a proper name is a person's own name. See, Wren \& Martin, High School English Grammar and Composition (New Delhi: S. Chand \& Company, ed. 6th in 2005, 1st ed. 1936)

[17]. Gowers, Ernest (2014), Gowers, Rebecca ed.Plain Words Particular .

[18]. Armstrong, D.M.(2010). Sketch for a systematic metaphysics. (Oxford: Oxford Unversity Press).

[19]. Amin, Aiman, An Nahw al Kafi (Kairo: Daar Al-Khaldun, v-1) .

[20]. Charles Hockett, (1958). A course in modern linguistics.( Oxford, Clarendon Press, 1990).

[21]. Dr. Syed Ali, Arabic for Beginners,(Chennai: Royapetteh, ed. 1997, 1st ed. 1988 CE.) . 
[22]. Abul Hashem, Arabic Made Easy (Chittagong: Bangladesh Co-Operative Society Ltd.) .

[23]. Ali Al-Zarim, An-Nahu Al-Wadih (Cairo: Dar-i-Ibn Khaldun, V-1, second edition1996, V-1,) .

[24]. Ali Ibn Abdullah, Sharhul Azrumiyyah (Cairo: Dar as-Salaam, Egypt V-1).

[25]. Wenmeier, Sally, Oxford Advanced leaerners Dictionary ( New York: Oxford University Press, ed. 7th 2005, ed. 1st 1857 CE)

[26]. Tahir Al- Bayati, Al -lugah Al-Engligiyyah (Beirut: Al-Ahliyyah, Lebanon).

[27]. Hans Wehr, A Dictionary of modern written Arabic, (Beirut, Maktabatu Lebanon, 3rd edition 1980)

[28]. Roger D. Woodard, the Cambridge Encyclopedia of the World's Ancient Languages.

[29]. P. Jr.Kyle, the Cambridge Encyclopedia of the World's Ancient Languages.

[30]. Haywood \& Nahmad, A New Arabic Grammar of the Written Language (New York: Columbia University Press, second edition 1997 first published in 1965)

[31]. Ibn Hisham al-Ansari, Sharh Shudhawr al-Dhahab fi Ma'rfah Kalam al-Arabi (Beirut: Dar al- Marefah, 1999)

${ }^{1}$ Charlton T . Lewis and Charles Short. A Latin Dectionary ( Newyourk: Oxford University Press. Fisrt ed.1875, last ed.1947).

${ }^{2}$ Merriam - Webstar Dectionary (online) Merriam - Webstar, Incorporated 2014

${ }^{3}$ Loos, Eugene., et al 2003. Glossary of linguistic terms; what is noun?

${ }_{5}^{4}$ Al-Bayati, Tahir, Al-Lugah Al-Engiligiyyah (Beirut: Al-Ahliyyah publishers, $2^{\text {nd }}$ edi. 2008) p. 171

${ }^{5}$ Wren \& Martin, High School English Grammar and Composition (New Delhi, S. Chad \& Company, 7361, Ram Nagar) p.5

${ }^{6}$ Nazib, 'Izuddin Muhammad, Qawai'dullugah Al-Engiligiyyah (Cairo: Ibn Sina bookshop, Helopolis , $8^{\text {th }}$ edi. 1996 ) p.11

${ }^{7}$ Jeckendoff . Ray. (2002) “ Semantics as a generative system”, Foundations of language;brain, meaning, grammar, evolution (PDF), Oxford University Press. ISBN 0-19-827012-7.

${ }^{8}$ Muhyi al-Din 'Abd al-Hamid, Muḥammad, Sharh Ibn 'Aqil 'ala Alfiyyat Ibn Malik wa-ma'ahu Kitab Minhat al-Jalil bi-Tahqiq Ibn 'Aqil. (Cairo: Maktab al-Turath,v-1) p.14

${ }^{9}$ Assyyed Al-Hashemi, Qawaed Alluyah al Arabiyyah ( Beirut:Dar al kutub) p.18

${ }^{10}$ Dr. Zawarez Marti Abdul Maseh, Ma'zamu Qawa'id-ul 'Arabiyyatul al- 'Alamiyyah (Beirut: Maktabatu Lebanon Nasherun, $2^{\text {nd }}$ ed. 1995) p.7

${ }^{11}$ Abul Hashem, Arabic Made Easy (Chittagong: Bangladesh Co-Operative Society Ltd.) p.11

${ }^{12}$ Larry Beason (2005), The Mc Graw-Hill Handbook of English Grammar and Usage, (Chicago: Mc Graw publication ) p.4

${ }^{13}$ Dr. Nazeeb , I'zuddin Muhammad, Qawaidullugah Al Arabiyyah (Cairo: Maktabatu Ibn Sina, Haliopolis, $8^{\text {th }}$ edition,19 94.) p. 37

${ }^{14}$ Haywood \& Nahmad , A New Arabic Grammar of the Written Language (New York: Columbia University Press, second edition 1997 first published in 1965) p.37

${ }^{15}$ Proper means one's own. Hence a proper name is a person's own name. See, Wren \& Martin, High School English Grammar and Composition (New Delhi: S. Chand \& Company, ed. $6^{\text {th }}$ in $2005,1^{\text {st }}$ ed. 1936) p. 7

${ }^{16}$ Larry Beason (2005), The Mc Graw-Hill Handbook of English Grammar and Usage, p.9

${ }^{17}$ Dr. I'zuddin Muhammad Nazeeb, Qawaidullugah Al Arabiyyah (Cairo: Maktabatu Ibn Sina, Haliopolis, $8^{\text {th }}$ edition,19 94.) p. 38

${ }^{18}$ Gowers, Ernest (2014), Gowers,Rebecca ed.Plain Words Particular . pp.189-190.

${ }^{19}$ Armstrong, D.M. (2010). Sketch for a systematic metaphysics. (Oxford: Oxford Unversity Press). P.2

${ }^{20} \mathrm{http}: / /$ grammar.yourdictionary.com

${ }^{21}$ Amin, Aiman, An Nahw al Kafi (Kairo: Daar Al-Khaldun, v-1) p. 89

22 Gender: "Gender comes from Latin genus, kind or sord". See, Wren \& Martin, High School English Grammar and Composition (New Delhi: S. Chand \& Company, 7361, Ram Nagar, $6^{\text {th }}$ ed, 2005 A.D, $1^{\text {st }}$ in 1936) p.9

${ }^{23}$ According to English grammar each noun belongs to specific genders. In this language, there are four types of gender;

i) Masculine Gender: A noun that denotes a male life is said to be of the masculine gender. e.g. boy, father, man, cock, king.

ii) Feminine Gender: A noun that denotes a female life is said to be of the feminine gender, such e.g. girl, mother, women, princess, queen etc.

iii) Common Gender: A noun that denotes either a male or female is said to be of the common gender. For example: e.g. spouse, child, etc. 
iv) Neuter Gender: A noun that denotes a thing which is neither male nor female, i.e. a thing without life, is said to be of the neuter gender. Examples of such gender are: coat, flower, house, picture etc.

${ }^{24}$ Charles Hockett, (1958). A course in modern linguistics.( Oxford, Clarendon Press, 1990) p. 231

${ }^{25}$ The whole Arabic words are either masculine or feminine; i.e. Arabic has two genders, expressed by pronominal as well as by verbal agreement. Agreement with numerals (عدد) shows a peculiar 'polarity'. The genders are usually referred to as masculine and feminine, but the situation is more complicated than that. The (مؤنث-feminine) gender is also used to express 'singularizes'. The marker for the feminine gender is a (") suffix, but some nouns without this marker also take feminine agreement (أمز -mother) ard (أرض) -earth). See, Aiman Amin, An. Nahu al-kafi (Kairo: Dar-al-khaldun,vol -1) p.5

${ }^{26}$ Dr. Syed Ali, Arabic for Beginners,(Chennai: Royapetteh, ed. 1997, $1^{\text {st }}$ ed. 1988 CE.) p.32

${ }^{27}$ Abul Hashem, Arabic Made Easy (Chittagong: Bangladesh Co-Operative Society Ltd.) p.13

${ }^{28}$ The Arabic letter (o) is called 'التاء المربوطة '.Please see, Hans Wehr, A Dictionary of Modern Written Arabic,(Beirut: Maktabatu Lebanon, $3^{\text {rd }}$ edition 1997) p. 412

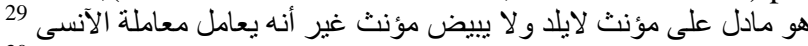

30 ،Caliph (خلامة) very learned are exceptions"

${ }^{31}$ Ali Al-Zarim, An-Nahu Al-Wadih (Cairo: Dar-i-Ibn Khaldun, V-1, second edition1996, V-1,) p.89

${ }^{32}$ Ali Ibn Abdullah, Sharhul Azrumiyyah (Cairo:Dar as-Salaam ,Egypt V-1) p.29

33 "What is Number?", Dictionary of Linguistic Terms (oneline)

34 Wenmeier, Sally, Oxford Advanced leaerners Dictionary ( New York: Oxford University Press, ed. $7^{\text {th }} 2005$, ed. $1^{\text {st }} 1857$ CE) p. 104

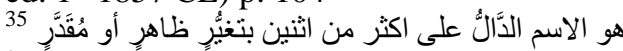

هو مَا دل على مفردٍ 36

37 المثنى هو وضعا لإِثنين، وأغنى عن المتعاطفين

38 هو ما دل على أكثر من اثنين

${ }^{39}$ Tahir Al- Bayati, Al -lugah Al-Engligiyyah (Beirut: Al-Ahliyyah, Lebanon), p.110

${ }^{40} \mathrm{Ali}$ Al - Zarim, An-Nahu Al-Wadih, V-1, p. 49

${ }^{41}$ Abul Hashim, Arabic Made Easy, p.25

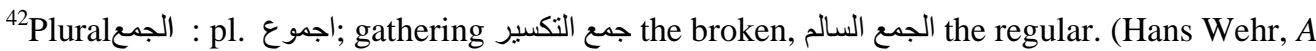

Dictionary of modern written Arabic, (Beirut, Maktabatu Lebanon, $3^{\text {rd }}$ edition 1980) p,135

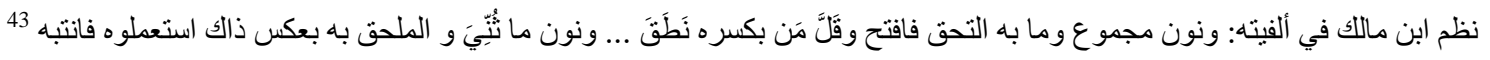

لم تكن ألألف والتاء -كلتهما- زائدتين-لم تكن الكلمة جمع مؤنث سالماإذا 44

جمع التكسير في اللغات السامية هو جمع يبم بتغيير الكثير من الأحرف في الإسم المفرد ودون الإعتماد 45

${ }^{46}$ Roger D. Woodard, The Cambridge Encyclopedia of the World's Ancient Languages, p. 440.

47 P. Jr.Kyle, The Cambridge Encyclopedia of the World's Ancient Languages. P.342

${ }^{48}$ Haywood \& Nahmad , A New Arabic Grammar of the Written Language (New York: Columbia University Press, second edition 1997 first published in 1965) p.37

${ }^{49}$ Ibn Hisham al-Ansari, Sharh Shudhawr al-Dhahab fi Ma'rfah Kalam al-Arabi (Beirut: Dar al- Marefah, 1999) p. 66. 